\title{
SPEECH ACT IN INDONESIAS' SHAMPOO ADVERTISMENT
}

\author{
Risna Rudiawati ${ }^{1}$, Vivi Fitria ${ }^{2}$, \\ ${ }^{1}$ IKIP SILIWANGI \\ 2 IKIP SILIWANGI \\ ${ }^{1}$ risnarf7@gmail.com, ${ }^{2}$ vivifitria85@gmail.com
}

\begin{abstract}
Advertisement as the tool for communicating and promoting a specific product to the customer brings a new phenomenon on the use of language. Every utterance has the function, from a very simple point of view advertisement is objected to making customer buying their product. Illocutionary act as an action via utterance are able to project the main objective of the advertisement, wheatear this advertisement expressing feeling, representing facts, declaring the point of view, promoting question, and promising goal. This research objects to revile the speech act used in Indonesian shampoo advertisement using qualitative study. This use 84 utterances from 5 brand of shampoo. Those 84 utterances were taken from video ads of 5 shampoo product in Indonesia. As the result, Shampoo ads in Indonesia has $\%$ of declarative Speech act, \% Commission Speech act, \% Representative Speech act, \% Expressive Speech act, \% Directive Speech act. This result shows that Shampoo product in Indonesia intends to promote their product by declaring their ability in giving the best result for the customer whether it gives a shiner hair, softer hair, stronger hair or others.
\end{abstract}

Keywords: Speech acts, Indonesias' Shampoo

\section{INTRODUCTION}

Advertisement as tool for communicating and promoting a specific product to the costumer bring a new phenomenon on the use of language. Every utterance has function, from a very simple point of view advertisement is objected to make customer buying their product. Ads are all forms non-personal presentations and promotions ideas, goods, or services by certain sponsors to pay. The ads are of various kinds, almost every need of public goods and services are advertised in both print and electronic media. One of them can be found in beauty product advertisement that is currently found in television electronic media. According to a more recent definition, advertising "is a communication technique that involves running a complex persuasive process, for whose realizations are used a number of specific tools, able to cause psychological pressure on the concerned public. The initiator of the advertising communication actions is the sponsor, who in order to achieve communication objectives, wants to send an impersonal message to a well-defined audience regarding the enterprise, its products or services."(Nichifor, 2014).

Pragmatics is about how to use language in communication. The meaning studied in pragmatics is influenced by contexts; who is the speaker, where the conversation taking place, when it happen, who is the interlocutors and others. It is supported by (Levinson, 2011) in the journal 
of (Agusta \& Rosa, 2012) states that pragmatics is the study of relationship between language and context. Language and context are two different things that cannot be separated each other, language is used in context and context will affect the meaning of language or utterance used by a speaker. That is, the meaning of speech will be different if used in different contexts or situations. Consequently, the listener may be able to have views or opinions about the utterances mentioned in different contexts. According to (Levinson, 2011) Pragmatics, in a traditional sense, comprises "the study of language usage", to be distinguished from syntax, which is "the study of combinatorial properties of words and their parts ", and from semantics, "which is the study meaning “.

According to (Altikriti, 2011) speech act theory attempts to explain how speakers use language to accomplish intended actions and how hearers infer intended meaning form what is said From the above definition we can say that speech actg is an action that perfomed through unterences. Moreover, with speech we can get more, such as information, ask questions, give or get advice, invite, and suggestion, plan something and others. Speech act can be simple defined as how a language is used to meet our needs in a speech occasion. In relation to the usages of language, (Yule, 2006) statets that speech act as the action performed by a speaker with an utterance. The action performed by producing and utterance will consist of three related acts: locutionary act, illocutionary act, and perlucotionary act. Locutionary act is the basic act of utterance, or the basic act of producing a meaningful linguistic expression, illocutionary act is the act of what the speaker intends to communicate to the addressee, and perlocutionary act is the act of interpreting of what the speaker says.

(Yule, 2006) said that illocutionary act is the act which is performed via communicative force of utterance. He said that we might utter to make a statement, an offer, an explanation for some others communicative purpose. (Wijana, 1996) says that if the speakers means exactly what they want and mean, it can be called as literal speech act but if the speakers do not mention what they say and what they intend to the hearers, it can be called non literal speech act. (Searle, n.d.) supported by (Yule, 2006) in (Nyota \& Mutasa, 2008) classified illocutionary acts into five types: declaratives, representatives, expressive, directives, and commissives.

(Searle, n.d.) finds that communicative functions are reducible to five major classes, there are representatives, directives, expressive, commissives, and declaratives;

1. Declarations are those kinds of speech acts that change the world via their utterance, as the sample in illustrated, the speaker has to have a special institutional role, in a specific context, in order to perform a declaration appropriately. Declarations required extra linguistic institutions for their performance. The direction of fit is both "words to world" and "world to words", as the actual expression of the declaration brings about a change in reality. In outlining the above functions of language, Searle has made it clear that he considers language as fulfilling a finite and determinate number of functions. In using a declaration, the speakers change the world via words. They change the state of the world in an immediate way. A similar view has been adopted by Leech (1983: 104-105) 
who, nevertheless, bases his classification of illocutionary functions on different criteria. In short directives is used to expresser the speaker's desire.

2. Representatives are those kinds of speech acts that state what the speakers believe to be the case or not. The speaker's purpose in performing representatives is to commit him /her to the belief that the propositional content of the utterance is true. Statement of fact, assertions, conclusions, and descriptions, as the example of the speaker representing the world as her or she believes it is. Representative, the speaker says how something is, or tries to make "the words match/it the world's" (or belief) to use (Searle, n.d.). In short representatives is used to expresses the speaker's belief.

3. Expressive are those kinds of speech acts that states and can be statements of pleasure, pain, likes, joy, or sorrow, as the example they are about the speaker's experience. In using an expressive, the speaker makes words fit the world (or feeling). They express how the speaker feels about the situation. Expressive is varying with regard to propositional content. Another kind of statement that can be used in expressive are: thanking, apologizing, welcoming, deploring. In short expressive is used to expresses the speaker's emotions.

4. Directive are those kinds of speech acts that speaker use to get someone else to do something. They express what the speaker wants. In performing directives, the speaker tries to get the hearer to commit him / herself to some future course of action (verbal or non verbal). They are commands, orders, invites, advice, begs, request, suggestions, as the example, they can positive or negative. In using a directive, the speaker attempt to makes world fit/match the words (via the hearer). They try to make the addressee perform an action. In short directives is used to expresser the speaker's desire

5. Commissives are those kinds of speech acts that speakers use to commit themselves to some future action. They express what the speaker intend. They are promises, plans, vows, threats, offers, refusals, pledges, and as the example, they can be performed by the speaker alone, or by the speaker as a member of group. In using a commissives, the speaker undertakes to makes world fit the words (via the hearer). They commit the speaker to doing something in the future.

In this study, the type of illocutionary acts proposed by (Searle, n.d.) supported by (Yule, 2006)) and (Nyota \& Mutasa, 2008) will be used in the process of analyzing data. This type is selected because it accommodates a clear classification of illocutionary acts and a complete guidance of classifying types

of illocutionary acts.

Researchers chose speech act as a field to study the language of beauty product advertising, because in speech acts speakers not only produce speech which contain only grammatical words and structures, but also shows the actions through the speech (Yule, 2006). Moreover, Illocutionary act as an action via utterance to project the main objective of the advertisement, wheatear this advertisement expressing felling, representing facts, declaring point of view, promoting question, and promising goal. This research unifies advertisement of shampoo product in Indonesia and Speech act theories. Speech act theories is one of the sub chapter 


\section{METHOD}

This paper presents how the data in this research are described and analyzed. The data are statements of shampoo Indonesian advertisements. There are 5 brand of shampoo such as Sunsilk, Zinc, Head and Shoulders, Dove and Treseme advertisements. The data which have been collected are analyzed and classified into types of illocutionary acts which are cited in by (Yule, 2006) and (Nyota \& Mutasa, 2008). In this paper only 85 data whose analysis are presented. Qualitative method used to present a descriptive representation of the data.

\section{RESULTS AND DISCUSSION}

\section{Results}

The data of this research was taken from the advertisement of 5 shampoo products; Sunsilk, Treseme, Head and Shoulders, Dove, and Zinc. There are 83 advertisements that use as a data source form all the products. From all the product The data from classification about communicative functions are reducible to five major classes; there are representatives, directives, expressive, commissives, and declaratives. Based on the results of research, it is known that the dominant form of illocutionary is a declarative sentence with a total of 33 or 39.29\% utterances from 83 speech data. The results of that study displaying sentence dominance declarative in product advertising beauty indicates existence something that is preached to listeners, usually in the form of content and efficacy contained in beauty products which can beautify its users. The detail percentage can be seen from the Figure 1.

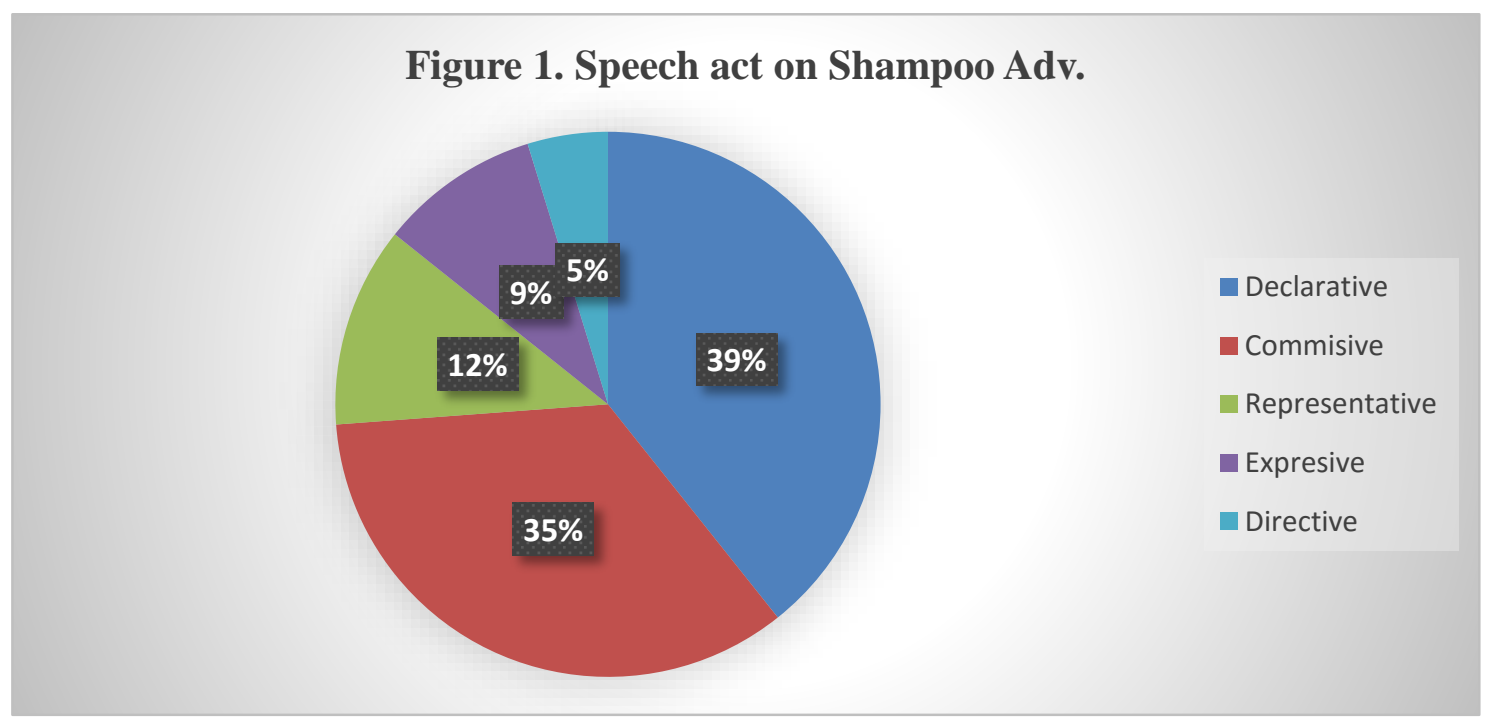

\section{Discussion}

1. Declarative 33 or $39 \%$

As mentioned this speech is the common type appear in Indonesian shampoo advertisement. From 83 utterances there 33 utterances that classified as declaratives. 
Declarative is a speech act that use to declare something based on the speaker provided fact to fits the certain phenomenon. Here are 5 most representative data of declarative utterance.

(1) "More than anti dandruff shampoo"

Data (1) is a product from shampoo Zinc refreshing cool version Samuel Zylgwyn as an actor in advertisement, then data (1) is a form of a declarative sentence illocutionary intended to preach something to the listener. Something that reported is information that the zinc shampoo is more than anti dandruff. They declaring supported by the fact that their shampoo is more than any other anti-dandruff shampoo. The word more in the advertisement shows their intention in declaring their product quality which is better than other shampoo.

(2) "Linda melupakan Roni dan rambut kusamnya dalam 5 minggu"

Data (2) is products from shampoo Sunsilk Urang Aring version 2004, in the data show the declarative sentence because give the information that Linda forgets about Roni and her dull hair in 5 week. Its means if the Sunsilk shampoo can change her dull hair and her problem with Roni has been done. This advertisement in other words declared that by using this shampoo you someone will lose their dull hair in only 5 weeks of usage.

(3) "Head and shoulders lebih baik dari shampoo terkemuka, mengurangi ketombe sejak pertama kali keramas, ketombe dan gatal takluk!"

Data (3) is product from shampoo Head and Shoulders Cool Menthol Version 2017, in the data show the declarative sentence illocutionary intended to preach something to the listener. It means that product more than better than other shampoo, and can detract the dandruff since the first use. The word more in the advertisement shows their intention in declaring their product quality which is more better than other shampoo.

(4) "Treseme keratin smooth, untuk rambut tetap lembut mudah diatur hingga 48 jam dalam kondisi apapun"

Data (4) is product from Treseme shampoo ads. The data shows that this product wanted to preach something to the listener. This advertisement also shows that they declare that they product has an ability to make the customer hair stay silk and manageable by stating rambut tetap lembut dan mudah diatur (silk and manageable hair). Moreover, this ads also declare that the customer hair will still look silk and manageable in 48 hours in all condition, this statement create a picture that this product wanted to change the costumer world by choosing this product, the consumer will have a silky, manageable hair for 48 hours in all situation.

(5) "Dove total hair fall treatment dengan tricazole, menutrisi dari akar rambut"

Data (5) is an Ads from Dove Shampoo. The data shows that this product wanted to preach something to the listener. This statement become a declarative by the use of the verb "dengan tricazole, menutrisi dari akar rambut" in English translation; with tricazole, give nutrition from root of the hair. The advertisement declares what the containment of this product and how this product effect to your hair. in other words this ads declares that the product can give nutrition to your hair. 
2. Commissives $29(34.52 \%)$

From 83 utterances there are 29 utterances or $34.52 \%$ data that classified as commisives speech act. Commissives are those kinds of speech acts that speakers use to commit themselves to some future action. Here are five most representative data:

(1) sunsilk rambutmu selalu mendampingimu. (sunsilk your hair always accompanying you)

Data (1) is taken from Sunsilk, this data is regarded as Commissive because this data give a promising statement by the use word selalu or always (English translated). This word indicating that if you use this shampoo means that your hare will always being part of you and be with you in all situation. The fact that this shampoo wants to oppose is that most of the product cannot last longer so then the hair become in problem again, but after using this shampoo all problems will gone. In short this statement promises something to the customers so this is Commissive statement.

(2) Treseme rambut indah salon setiap hari. (treseme the beautiful hair salon every day)

Data (2) is taken from treseme, this data is regarded as commissive because this data give a promising statement by the use word setiap hari or every day (English translated). The promising words can be seen from the entire clauses this advertisement give a promise to their customer that they will have a long lasting beauty of their hair when they use this product.

(3) Membantu menutrisi rambutmu dan menjadikannya lembut (help nourish your hair and make it soft).

Data (3) is take from head and shoulders, this data regarded as commissive because this data give a promising statement by the use word menutrisi or nourish and mejadikan or make (English translate). This statement give a promise to the customer that the product can nourish the hair and make the customers' hair smooth.

(4) Jadikan rambut lembut tanpa ketombe (zinc) (make hair soft without dandruff) Data (4) is taken from zinc, this data is regarded as commissive because this data give a promising statement the use word jadikan or make (english translated). This advertisement promises a hair transformation. From the clause above we can see that this product has ability to smoother your hair and free dandruff hair. its indicating that after using this product the customer will have a smooth hair and no dandruff hair.

(5) Dove total damage treatment membantu menghentikan kerusakan sebelum terjadi. (Dove total damge treatment help stop the damage before happen)

Data (5) is taken from Dove, this data is regarded as commisive because this data give a promising statement the use word menghentikan or stop (English translated). This word indicating a promise because the meaning appeared form this clause is that by using this product you will no longer have hair problem. This product will stop the damages even before the damage occur. 
3. Representative $10(11.90 \%)$

From 83 utterances there 10 utterances or equal to $11.90 \%$ of data that classified as representative speech acts. Here are 5 most representative data of representative utterance.

(1) Lihat! tak ada lagi ketombe dan rambut rontok

Data (1) is taken from tresemme, this data is regarded as representative because this data give an action to show the result which is want to make the audiences believe with use the word lihat or see (English translated).

(2) Kepercayaan diri berawal dari treseme scalf care

Data (2) is taken from tresemme, this data regarded as representative because this data show the fact to make the audiences believe with their product and support with use the word kepercayaan diri or confident of customer (English translated).

(3) sekarang aku bisa terlihat tanpa ketombe, tercium tanpa ketombe, dan merasakan sensasi tanpa ketombe,

data (3) is taken from zinc, this data regarded as representative because this data show the fact with showing the result from their product to make the audiences believe. This data also use the word tanpa or without with repeating that word until three times. (English translated)

(4) Cuaca panas, angin ataupun polusi lihat rambutku masih tetap lembut

Data (4) is taken from tresemme, this data regarded as representattive because this data show the result to the audiences with use the word lihat or see to make them believe if their product can make our hair still soft although in hot weather, wind or polution. (English translated)

(5) Tenang atasi semua masalah dengan satu solusi.

Data (5) is taken from tresemme, this data regarded as representative because this data want to make the audiences believe to their product with show the result used the word tenang or calm (English translated).

4. Expressive: $8(9.52 \%)$

As the result from 83 utterances there 8 utterances or $9.52 \%$ of the data is classified as expressive. Expressive speech act is a speech act that indication emotion of the speaker. Here are 3 most representative data;

(1) Untung aja ketemu sama dove (im felling lucky to meet dove)

This data (1) show expresive speech act because this data express the feeling of the customer after using this products. This feeling is indicated by the use of word untung or lucky (English tarsnlated). As we now lucky in part of speech is adjectives and its indicating happiness to have something with you. In other words, word lucky indicating felling that own by the cutumer after they use this product.

(2) Waw rambut aku lembut sekali (Wow, my hair is very soft) 
This Data (2) indicating expresive speech acts because this claus use interjection wow. As we now interjection is part of speech that use to indicating feeling. Wow in the statemt above show expression of happiness. Customer in advertisment feels happi because this perodet make her hair smooth and silk.

(3) Untungnya hair stylish ku merekomendasikan perawatan professional (im feeling lucky may hair stylish recommends a professional nourishing product)

Simillar to data (1), data (3) is regareded as Expresive speech act by using the word untungnya or lucky (English translated). This uterence shows that the customer feeling lucky and happy because they use hair product that been recommended by prpfeesional in this case is the product.

5. Directive : 4 (4.76)

From 83 utterances there are only 4 utterances or $4.78 \%$ of the data that is classified as declaratives. Directive are those kinds of speech acts that speaker use to get someone else to do something. They express what the speaker wants. Here are 2 most representative data:

(1) Berfikir dove bukan jawaban rambut rontok? fikir lagi!

Data (1) is regarded as directive speech acts, as we know form the definition, this type of speech act is ask the reader or the hearer to do something in other word the simplest indicator of this speech act is the use of imperative caluse. Data one is imperative word because it use exclamation mark. In short this dta is regarded as directive speech actg becous this data use imperative clause.

(2) Kamu bisa hindari ketombe dan minyak sepanjang hari. Saya rekomendasikan head and shoulders. (You can avoid dandruff and oily hair all day long. I recommend head and shoulders)

Data (2) is regarded as directive speech act this advertisment is recommending the custumer to use this shampoo. The word recomanding indicate that we want to make people do what we want. In other word, word recommendation or to recoment is directive because it ask people ti do something.

\section{CONCLUSION}

From the reslut of the analysis it can bee sen that indonesias' shampoo advertisment contain all speech actg based on Yule's speech acts theory. indonesias' shampoo advertisment use Declartive speech act as much $39 \%$ of 83 unterences. $34 \%$ or 29 uterence is Commisive, 11.90 $\%$ of 83 or 10 unterence is representative, 8 unterence or $9.52 \%$ unterences is expresive, and 4 uterences or $4.76 \%$ is directive. from the data Indonesias' shampoo advertisment use more declaratives, its indicates that shampoo Indonesia prefer to declare something based on provided fact to fits the certain phenomenon.

\section{ACKNOWLEDGMENTS}

The writers diliver highest aprresiation to all people who contributes in completing this research. 


\section{REFERENCES}

Agusta, \& Rosa. (2012). Types Of Illocutionary Acts In The Slogans Of Tourism Destination Advertisements. FBS Universitas Negeri Padang.

Altikriti, S. F. (2011). Speech Act Analysis to Short Stories. ACADEMY PUBLISHER Manufactured in Finland, 2(6). Retrieved from https://doi.org/10.4304/jltr.2.6.1374-1384

Levinson, S. C. (2011). Pragmatics. New York: Cambirdge Univesity Press.

Nichifor. (2014). Theoretical Framework Of Advertising - Some Insights. University of Bacau.

Nyota, S., \& Mutasa, D. E. (2008). The Communicative Impact of Shona Commercial Advertisements : A Speech Act Theory Analysis Approach, (June), 92-106.

Searle, J. R. (n.d.). A Taxonomy of Illocutionary Acts.

Wijana, I. D. P. (1996). Dasar Dasar Pragmatik. Yogyakarta: Andi Offset.

Yule, G. (2006). The Study of Language (Third). New York: Cambridge University Press. 